Article

\title{
Stories of Favourite Places in Public Spaces: Emotional Responses to Landscape Change
}

\author{
Maraja Riechers ${ }^{1, * \mathbb{C}}$, Werner Henkel ${ }^{2}$, Moritz Engbers ${ }^{1}$ and Joern Fischer ${ }^{1}$ \\ 1 Faculty of Sustainability, Leuphana University of Lüneburg, 21335 Lüneburg, Germany \\ 2 NaturArte, 28205 Bremen, Germany \\ * Correspondence: Riechers@leuphana.de
}

Received: 13 June 2019; Accepted: 12 July 2019; Published: 15 July 2019

\begin{abstract}
Understanding emotions is necessary to analyse underlying motivations, values and drivers for behaviours. In landscapes that are rapidly changing, for example, due to land conversion for intensive agriculture, a sense of powerlessness of the inhabitants can be common, which may negatively influence their emotional bond to the landscape they are living in. To uncover varied emotional responses towards landscape change we used an innovative approach that combined transdisciplinary and artistic research in an intensively farmed landscape in Germany. In this project, we focused on the topic of favourite places in public spaces, and how change in such places was experienced. Drawing on workshops and interviews, we identified themes of externally driven societal and internal personal influences on the public favourite places. "Resilient" emotional responses towards landscape change showed a will to integrate the modifications, while "non-resilient" responses were characterised by frustration and despair. We argue that identifying emotions towards change can be valuable to strengthen adaptive capacity and to foster sustainability.
\end{abstract}

Keywords: land art; landscape change; leverage points; nature connectedness; sustainability transitions; thematic analysis; transdisciplinary research

\section{Introduction}

Scholars and laypersons alike increasingly express discomfort with an ever accelerating growth-based economy and the resulting global environmental changes [1-3]. The current economic system with its premise of unlimited growth can cause conflicts with values held by individuals $[4,5]$. For example, food production is increasingly fragmented, with consumers geographically removed from the products and sites of production [6], leading to a sense of "food from nowhere" [7]. The social and ecological impacts of food production and exchange are rendered invisible to consumers, and can also be alienating for those experiencing industrialized food productions in their home landscapes [6]. This sense of alienation can stem from different normative standpoints on how the land should be used (instead) [8].

Landscape change can be vast and rapid, such as in the Chaco region in South America which is subject to the highest rate of land clearing in the world [9]. Elsewhere landscape change has been more gradual. For example, the use of agricultural land in Lower Saxony, Germany, where our study area is situated, is increasingly intensified. Here, maize cultivation increased from $\sim 11 \%$ of the total agriculturally used land in Lower Saxony to $21 \%$ in 2016 [10,11]. Other widespread contemporary changes in landscapes include changes in social composition (e.g., in traditional cultural landscapes where smallholder farming is being lost) [12], changes in the landscape horizon (e.g., through wind parks, deforestation or re-forestation [13]), and widespread losses in biodiversity [14].

Generating a better understanding of how landscape change influences the emotional worlds of inhabitants can be important as a first step to highlight possible intervention points to strengthen 
adaptive capacity and foster sustainability by helping inhabitants to navigate change. Emotional responses to change have been surveyed regarding education (see overview in Reference [15]), yet mostly lacking in landscape studies. Hence, in our study, we aimed to (i) uncover emotional responses of inhabitants to landscape change; and (ii) elicit areas of intervention to empower local communities. We show that while not always conscious, reactions towards landscape change are often intense and vary from resilient responses that aim to incorporate the new reality, to non-resilient reactions of retreat and despair. Resilience, in this context, refers to the ability of a social-ecological system with its inhabitants to maintain its essential functions, including the capacity to adapt to future changes [16].

While most efforts to combat detrimental environmental changes have focused on changing specific parameters (e.g., the rate of land clearing) or relationships between parameters (e.g., increasing fines to prevent illegal land clearing), this often has not fundamentally changed the trajectories of the systems [17]. Addressing more deeply rooted causes of unsustainability, in contrast, is more difficult to do but may hold greater potential for system transformation [18]. This broad perspective, in turn, dictates that a diversity of approaches to knowledge production is embraced. Suitable approaches need to be able to take into account normative aspects, inequalities, politics and power asymmetries and work more directly across the interface of science and practice [19].

Against this background, in this paper, we explore issues of landscape change and people's emotional responses towards it through engaging with art-based research called social land art within a transdisciplinary case study [20] in the district of Oldenburg, Germany. Social land art links art, society and science and builds on a strong notion of participation [21,22] that in this study was fostered through intensive workshop settings that included discussion and the creation of art itself.

Following an explanation of the study site, we outline the transdisciplinary research approach including the involvement of a network of artists, and we describe our methods of data collection and analysis. We then present the results, showing how emotions towards landscape change were expressed. The paper concludes with a discussion that highlights the importance of understanding emotional responses as potential intervention points for sustainability transformation.

\section{Methodological Approach}

\subsection{Study Site}

The district of Oldenburg (Landkreis Oldenburg) is located to the South-East of the city of Oldenburg (approximately 175,000 inhabitants [10]) in the mid-western part of Lower Saxony, Germany. The district covers approximately 100,000 ha, of which two-thirds are used agriculturally, predominantly as cropland. The percentage of maize (silage and grain maize) grew from $18 \%$ in 1996 to $32 \%$ in 2015 [11].

Our study was part of a transdisciplinary collaboration [21] with the artecology_network, a German-wide collective of artists. In the district of Oldenburg, the involved artists seek to create awareness and possible solutions for land-use and nature conservation through close interaction with local actors.

\subsection{Material and Methods}

Our study was based on a close collaboration between an artist and an academic researcher on the topic of favourite places in public spaces. The art form used by the artist was social land art which sees itself as a link between art, society and science and entails a strong notion of participation [21]. The process of data collection was based on previous art workshops conducted by the artist. Problem framing and research questions were developed in close collaboration between the researcher and the artist. To address the overarching goal of uncovering emotional responses towards landscape change, the collection of empirical data followed a participatory qualitative research approach (Figure 1). Data was collected by the academic researcher in a setting organized by the artist. The project was structured as follows: Workshops were the core of the interactions starting with two-days in August 2017, one-day 
in September 2017, and a one-day closing workshop in February 2018. Between September 2017 and February 2018 all participants (excluding the artist) worked with and created art in their favourite public places (Figure 1, Figure A1 in Appendix A), which were visited and discussed on site at the closing workshop afterwards.

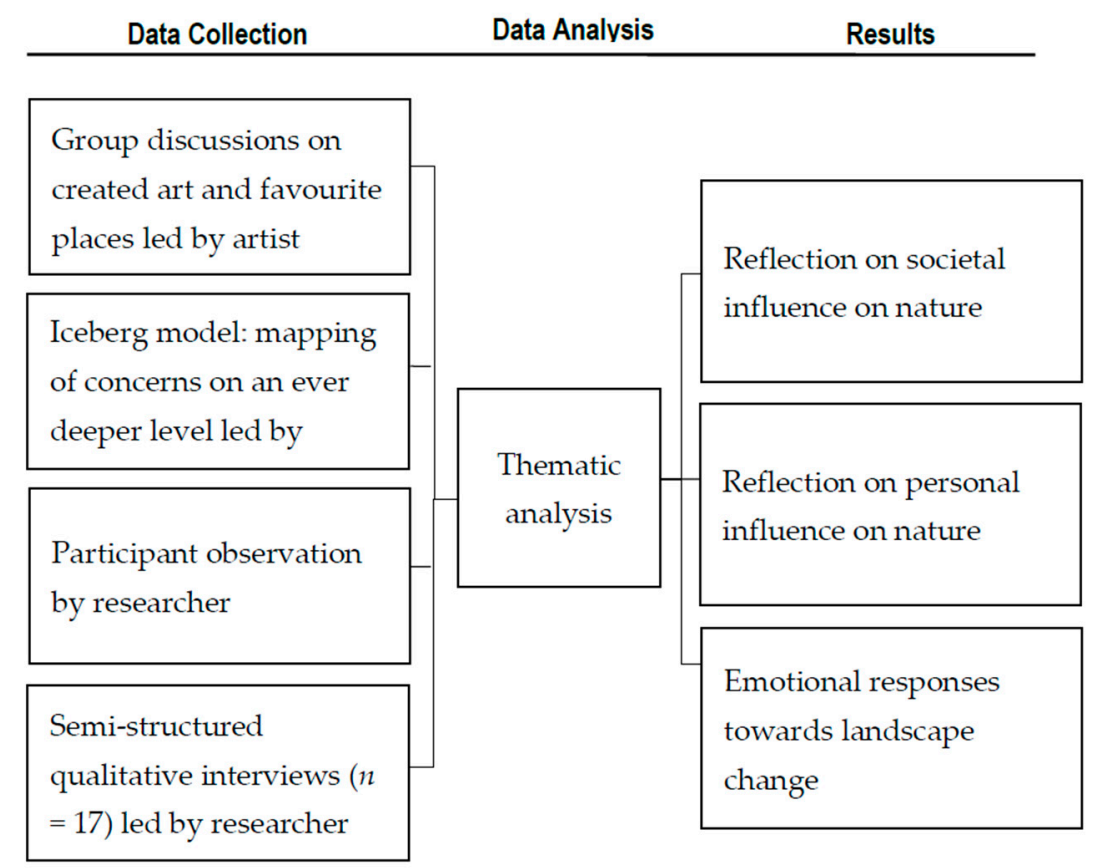

Figure 1. Overview of the data collected in 2017/2018, data analysis and structure of results.

The workshops included crafting and design sessions led and supported by the artist on topics such as the influence of their own artwork on places through various artistic expressions ([23], Figure 1, Figure A1). Action focused sessions, evolving around practical art installations done by the participants, alternated with reflective sessions. Haptic and sensual experiences with natural objects and processes of art creation in trial and error fashion (colour, pattern, structure, strong and light restructuring of the place) were the focus of the artist-led active session parts. Reflections focused on participants' meanings of nature, descriptions of their favourite places and their relations to and influences on them, which was led either by the artist or the academic researcher.

Participants were able to register without charge for the project, which was advertised through local news media, resulting in eight participants (three male, five female) including the artist and the researcher. Participants shared an affinity towards art and stated a high importance of nature in their lives, which was reflected in their professions or hobbies. Further participants were residents of the area and some were acquainted with each other.

Drawing on these workshops, the following data was collected by the researcher: (i) audio recordings ( $8.4 \mathrm{~h}$ of group discussions), (ii) participant observations, and (iii) qualitative workshop data such as mapping of concerns and an iceberg model [24,25]. Another 17 additional interviews on nature connectedness in one commune in the district of Oldenburg with local experts and informed laypersons knowledgeable of the landscape were conducted to complement the data. Those interviews were conducted simultaneously for a separate international study by the first author. Those interviews were collected using problem-centred interviews with a semi-structured interview guideline [26]. The guideline included sections on interviewees' human-nature connectedness and their experience of landscape change that happened in the last decades and, how these influenced interviewees' lives. We interviewed a diversity of informed laypersons and experts who we expected to be connected to a given landscape (e.g., farmers, foresters, policymakers, long-term inhabitants, priests) and 
used snowball sampling to reach possible interview partners and cover contrasting opinions [26]. The interviews had an average length of $75 \mathrm{~min}$ and were held in German by the first author. In this paper the results from parts of the interviews were included in the data analysis of this study, to have a more informed overview of occurring landscape changes and to contextualize statements of the participants.

Data used in the paper were analysed based on a modified thematic analysis [27]. The modified thematic analysis aimed at identifying patterns of meaning across the whole dataset, combining multiple forms of data (recordings, observations, qualitative workshop data, and interviews). We identified patterns (societal influences on favourite places; personal influences; spectrum of "resilient" responses to those) through a process of inductive data coding and structuring (comparable to Reference [28]) and pattern development and revision. This approach entailed a close discussion with the artist about observations and preliminary results after the workshops and in the data analysing process. This implicated iterations between an inductive development of patterns and data generation in workshops to allow for the identification of underlying meanings and continuous refinement of themes. Furthermore, preliminary results were used in the preparation of the next meeting to highlight questions or fill in existing gaps in the data. For example, after the first workshop, the researcher noted a gap between the emotional depth which was achieved by the art and the explanation of what triggered those emotions. Hence, the iceberg model was used to express underlying drivers of emotions in words and speech. The iceberg model exercise created a strong impact on the participants and hence was referred to by them in later workshops.

\section{Results}

Results of the workshops ranged from art installations that were created by the participants at their favourite places and discussions around art and favourite places during the workshops. The art was defined by the artist as social land art, as a dialogue between art, society and science. Social land art is strongly process-based, thus neither the art installations nor photographs thereof constitute the final outcome (Figure 1, Figure A1). We like to stress that the following results are mainly based on an analysis of qualitative data that has been generated in a transdisciplinary process in close collaboration between artists and an academic researcher. However, it is not an evaluation of the process and results of the artistic-research process of social land art. Yet, with its data analysis, it aims to bridge the gap between the haptic, emotional and creative experiences created by the artist in the workshops with the cognitive exercises and statements usually used in academic research. Other visible results of the art project can be found elsewhere (www.naturarte-wernerhenkel.de, Lieblingsplätze poetische Orte in der Natur, [23]).

In the first section of the results, we will present societal influences, such as changes by the landowners and changes in the surrounding landscape which changed the atmosphere of the favourite places of the participants and their responses towards it. In the second section, we will elaborate on the influence the participants felt they had on their favourite places and nature in general, and how they responded to their felt influence.

\subsection{Societal Influences}

Unlike favourite places on private property, favourite places in public spaces can be highly influenced by structural, societal landscape changes, as well as other individuals. Such influences can often neither be stopped nor reversed. In extreme cases, landowners or visitors can alter a public favourite place detrimentally, and such changes by individuals can be an indicator of broader systemic influences: "My favourite tree has been cut down. I thought: This cannot be true. They cannot cut this one here!" In this case, even though the participant tried to get hold of the responsible person because the tree had been cut illegally to expand agricultural land " $[. .$.$] the big beautiful tree, which I loved, was of$ course gone." 
Even when a public favourite place itself is not changing directly, the surrounding landscape can be subject to intense changes, negatively affecting the participant's attachment to and atmosphere of the favourite place. General landscape changes such as intensification of agricultural land, manifested, for example in an expansion of maize fields, newly built biogas plants, animal stalls, or wind turbines that are visible in the distance. Increased infrastructure, such as more and better roads and more traffic also changed the atmosphere of favourite places. The atmosphere might also be changed more subliminally by the smell of industrial animal husbandry, by changing plant species composition, or by slow environmental changes such as climate change: "[ . . ] the biggest problem I see today is the nitrate problem. Ammonia. In the last around 20 or 25 years, the increase of nitrate-loving plants took on a dramatic scale. That did not exist before."

Response from Participants

In response to such collective influences, participants expressed concerns for themselves and their favourite places. One concern was expressed as the fear that in an intensively used landscape space for solitude vanishes. A safe haven for retreat, reconciliation and recreation was deemed as very important for interviewees' health. Further, participants stated that nature, in general, loses its magic and wonder. The time it can take to be able to fully relax at a place can be long, and frequent disturbances might prevent a feeling of rest. Another concern was: "What is left of nature?" This was posed especially in the summer months in which maize stands high across the fields. This concern was blended with a perceived threat to the survival of humans and other species, because "we cannot live without nature".

In the discussions, participants expressed a range of responses to external influences on their public favourite places. At one end of the spectrum was a "resilient" response: becoming aware of the impacts of externally driven change on natural health, and of the landscape changes, within the microcosm of a given small favourite place. This type of response encouraged working with the changes, incorporating them and evolving resiliently with an equal amount of nature connectedness and attachment in the new conditions. Participants with this response felt a sense of responsibility to enter into a public dialogue to change their own and others' perspectives. At the other end of the spectrum was a "non-resilient" response: a sense of frustration and emotional and experiential detachment from the place. Feelings such as sadness, despair and apathy were expressed due to a sense of responsibility for a place but a lack of agency. "The facts are just created, and then it is destroyed. And you are standing there and you are thinking: yeah. And now it is broken, what should I do now?"

\subsection{Personal Influences}

Apart from externally driven, societal influences, participants expressed concerns regarding their own influences on their public favourite places and nature in general. Those reflections covered day-to-day interactions with nature as well as the effects of their own artwork. Reflections on personal influences included an outright fear to disturb the atmosphere of the favourite place even through small scale artistic impacts. "My greatest threshold now is the concern, an inner resistance, to intervene in this place. To change something. To have a presence there." Participants were concerned they were a disturbing factor in an otherwise peaceful and stable place. Simultaneously, they were painfully aware that every action in one's life has an unavoidable influence on nature locally and globally. "This awareness, I called it realist-schizophrenia of my modern life. Because I know, even though as a gardener I work the whole time in and with nature, and teach permaculture etc. [ . . and my] intention [is] there. Yet, [I] still drive the car every day, shop in the supermarkets and I know all those chains and connections. [ ... ] but [we] are entangled in this system."

\section{Responses from Participants}

A non-resilient response to such concerns was discussed as descending into a downward spiral of blame, anger or despair regarding one's own negative influence and incapacity to counteract detrimental influences on nature. "[ ... ] a great, deep, fundamental pain, grief. Despair. Helplessness. 
Or often again a bewilderment about this state of semi-sleep-to just continue in this form of existence." A more resilient response was a discourse on transcending this dichotomy between the inconsequential and hypocritical unsustainable every-day behaviour and the ideal state of a sustainable and careful treatment of nature.

In a different theme, participants argued that a favourite place in a public space was artificially created and had to be maintained, for example through eliminating weeds, unorderly branches or unsightly shrubs. If the place was left unmanaged, the place could no longer convey a sense of belonging and connection. According to this discourse, managed land was beautiful, because this reflects effort and work put into it. Yet, within the same discourse participants also expressed concern regarding the intensification of use as well as overuse, especially with regard to agricultural practices. A suggested possible response was to acknowledge the plurality and diversities held and established by multiple persons, land use practices and demands on land. It was proposed to create a holistic self-awareness that is cognizant that the intensification of nature is driven by external land use intensification as well as by one's own (increasing) utilitarian values.

By the end of the workshop's most intensive session, there was a proposition for a general solution. Participants agreed to not look for the maximum efficiency of a piece of land through a focus on agricultural yields or revenues. Instead, participants argued for an "overall optimal" and holistic use that acknowledges diversity. This entailed making room for non-use while acknowledging the need to use land without guilt or blame. This required "harmonies next to each other", that is, ways to navigate and compromise between nature conservation, recreation, food and energy production.

\section{Discussion}

Due to the haptic, creative and conceptual approaches combined in the long-term artistic expression through-out and between the workshops this art project was able to uncover honest and often underlying emotions of the participants. As the focus of this project was not on the cognitive expression of problems or based on formal or scientific knowledge surrounding those, participants were free to use their senses and creativity to express themselves through physical manifestations of their feelings, before translating it together with the group into words. Both social land art and transdisciplinary research emphasise that research takes place not just for, but with people [22] hence both approaches helped to enable closer collaboration between art and science. The project idea and process was based on previous work done by the artist, the research problem and question were developed in close cooperation between the researcher and artist. This close cooperation led to questions such as: What is scientific data? or How can art and science be combined? What are the genuine qualities of the approaches? These questions were addressed by the artist and researcher in their transdisciplinary process. This approach shows novel ways to generate knowledge and suggests ways to combine artistic and academic approaches to uncover emotional responses to landscape change.

Our findings suggest that bringing in artistic research practices into transdisciplinary research can be helpful to uncover a deep emotional connection to landscapes, benefitting from the fact that art can be a catalyst for human emotions ("elicitation of aesthetical emotional meanings" [29]). We are convinced that the depth and honesty of complex (and contradictory) emotions and their connections to nature could not have been elicited with conventional research methods. Working artistically proved to be a way of helping participants understand and address their own problems through democratized research that incorporates a diversity of knowledge forms [30,31]. Additionally, the artistic process required active involvement by participants to go out into nature and observe, create and change natural places. By appreciating different forms of knowing and acting, and using dialogical ways to explore these, complexity, uncertainties and disputed values of various different actors involved can be made explicit $[16,19]$.

Our study showed deep-rooted attachment to and care for nature in general, as well as for specific public places. Externally driven, rapid landscape changes influenced participants' own involvement and responsibility towards 'their' landscapes. Moreover, participants also scrutinized their own 
influence on nature and their favourite places. The results showed a spectrum of concerns and responses that highlight the complexity of emotions that are rarely uncovered by conventional research methods. In general, emotions can fulfil a central functional role in the cognitive processes and can have a strong effect on peoples' behaviour $[29,30]$. Emotions can be understood as a filter through which factual knowledge is understood. They are influenced by needs and goals and linked to behaviour and decision making $[29,30]$. We postulate the importance to recognize emotions regarding sustainability and tap into them, for the full potential for transformational change. Assessing emotions or emotional affinity to nature, however, is difficult, shown through a debate about cognitive concepts that focus on individual beliefs and measure connectedness to nature as a cognitive concept instead of an emotional one $[29,31]$. However, emotions are seen as an approach to avoid a division between cognitive and affective processes [32]. Both can be drivers for change, yet deep emotional motivations and reasoning are complex and often not shown in public. Moreover, culture, individual maturity and education are closely intertwined with emotional reactions [33].

The district of Oldenburg provided many examples of a cultural landscape under change. Reactions towards change can be immediate, such as a burst of anger and frustration. In contrast, they can also be more implicit, such as an undirected feeling of helplessness or fear of one's own ignorance and apathy, which are only uncovered through contemplation. The precise nature of reaction to changes in the "natural world" is strongly influenced by personal understandings of what nature is or ought to be. For example, responses towards landscape changes may vary if nature is understood as a cultural landscape that includes the human component. In contrast to an understanding of a pristine, untouched wilderness [34], our results suggested that our participants in the district of Oldenburg understood nature as being dominated by humans. While we observed a spectrum ranging from the need of strong human management to a non-intrusive, cautious, empathy-driven approach to nature, both extremes are symptomatic of a perceived human-nature divide. Such a divide is seen probably particularly in heavily managed landscapes [35], which call for active management approaches to produce high revenue or alternatively, require active efforts to remediate environmental damages. Our approach clearly uncovered discomfort and underlying disagreement with the current landscape trajectory. Participants acknowledged that various parameters characterizing the landscape indicate increasing unsustainability, and recognized reinforcing feedbacks around profitability and land use intensity. Participants perceived landscape changes as an uncontrollable force driven by uneven power dynamics, especially when they felt emotionally and cognitively attached to the places under change. Thus, perceived landscape changes are related to people's feeling of belonging and attachment to places [32,36]. A perception of powerlessness, in turn, appeared to erode a sense of agency and empowerment, thereby undermining the motivation of local people to try to transform the system they feel uncomfortable with $[2,37]$. This raises questions about the differentiation between public and private spaces and in how far they allow for active participation and decision-making. Especially, when the emotional qualities for public places are often not considered when it comes to planning decisions. Deprivation of agency and a resulting disconnectedness could lead to apathy, disengagement and reluctance to engage emotionally and politically. In stark contrast, for some individuals, distress could foster active engagement, be it through changes in individuals' personal behaviour or through raising awareness and encouraging political engagement [38,39]. In yet other instances, emotional distress, in combination with feelings of urgency and helplessness can have adverse effects in the form of scapegoating those perceived to drive landscape changes, especially as emotional reactions often remain unconscious.

Based on our analysis, we see the following possible realms of leverage for improving the sustainability of the Oldenburg district: (1) Fostering collective knowledge generation to enable information flow and exchange can create mutual empathy and understanding, and thus prevent slipping into an unconstructive blame game. (2) The motivation and engagement arising from emotional discomfort could be made transparent in order to actively foster local transformational change as seen by the actors involved. (3) Meaningful participatory processes also would be favourable 
to stop a spiral of disengagement and apathy by strengthening information flow, creating knowledge and a sense of agency [40]. There is a clear need for transformative change that permeates the whole social system-from the emotions of individuals to attitudes of social groups, and ultimately to societal structures and processes [2].

\section{Conclusions}

We investigated emotional responses to landscape change, especially by agricultural intensification, through a transdisciplinary collaboration involving artistic research. We unveiled widespread subliminal discomfort with the current economic system. Participants expressed a spectrum of emotional responses, ranging from "resilient" incorporation of changes to "non-resilient" reactions such as frustration and despair. We understand emotions as being a lever for change, and our results highlight the necessity to more deeply engage with emotional responses to landscape change. This is important, we argue, because emotional responses are crucial regarding realms of leverage, such as (1) fostering dialogue and collective knowledge generation, (2) using a sense of discomfort as a motivational source for transformation, and (3) stopping a spiral of disengagement through meaningful participatory processes. This will include confronting issues of agency and participation regarding land-owners, land-users and regulating bodies. Normative attitudes of many actors may wish for a transformational shift, but the feeling of helplessness and inability to change the economic and political systems undermine their ability to actually work towards transformation. In a social and ecological system that feels uncontrollable and that is, for many, heading in a highly problematic direction, a sense of agency among those affected is crucial. We encourage applying innovative and unconventional research approaches that allow for exploring different ways of knowing and acting, such as transdisciplinary or artistic research, to identify and enable interventions towards a sustainability transformation.

Author Contributions: Conceptualisation and methodology by W.H. and M.R.; validation by M.R., W.H., M.E. and J.F.; formal analysis by M.R. and M.E.; Writing (original draft preparation, review and editing) by M.R., W.H., M.E. and J.F.; project administration by W.H. and M.R.

Funding: This research was supported by the Volkswagen-Stiftung and the Niedersächsisches Ministerium für Wissenshaft und Kultur funded project "Leverage Points for Sustainability Transformation: Institutions, People and Knowledge" (Grant number A112269).

Acknowledgments: We thank all participants for their honesty and engagement. This paper represents an integration output from a large transdisciplinary research project (Leverage points for sustainability transformation). Its production has only been possible with the input and participation of all project members even when they are not listed as authors. Full details of project members and their research are available at https://leveragepoints.org.

Conflicts of Interest: The authors declare no conflict of interest. 


\section{Appendix A}

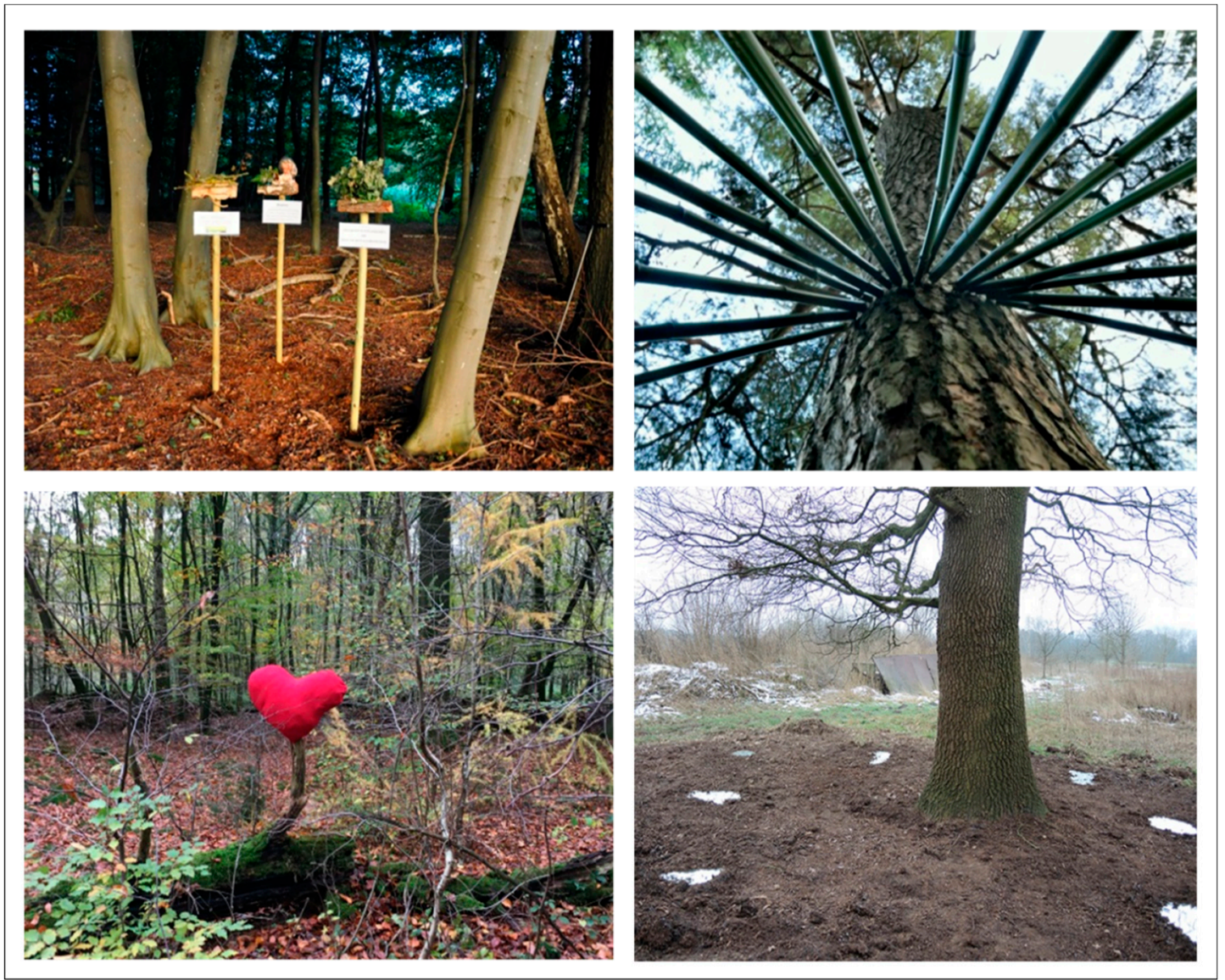

Figure A1. Explanation of some of the art (exemplified but not captured by the pictures below). The art is not captured in the pictures and confusion with art in a conventional sense should be avoided (neither the picture itself is art, nor the art on the picture is a good representation of what the "art" was). Description of some of the installations seen below can be found at https: //leveragepoints.org/2018/05/21/lieblingsplatze-poetische-orte-in-der-natur/.

\section{References}

1. Meadows, D.L.; Meadows, D.; Randers, J.; Behrens, W.W. The Limits to Growth; Universe Press: Paris, France, 1972.

2. Fischer, J.; Dyball, R.; Fazey, I.; Gross, C.; Dovers, S.; Ehrlich, P.R.; Brulle, R.J.; Christensen, C.; Borden, R.J. Human behavior and sustainability. Front. Ecol. Environ. 2012, 10, 153-160. [CrossRef]

3. IPCC. Climate Change 2014: Synthesis Report: Contribution of Working Groups I, II and III to the fifth Assessment Report of the Intergovernmental Panel on Climate Change; IPCC: Geneva, Switzerland, 2014.

4. Hopkins, R. The Transition Handbook: From Oil Dependency to Local Resilience; Devon Totnes Green Books: Cambridge, UK, 2008.

5. Eckerslay, R.M. Is the West really the best? Modernisation and the psychosocial dynamics of human progress and development. Oxf. Dev. Stud. 2016, 44, 349-365. [CrossRef]

6. Challies, E.; Newig, J.; Lenschow, A. What role for social-ecological systems research in governing global teleconnections? Glob. Environ. Chang. 2014, 27, 32-40. [CrossRef]

7. Campbell, H. Breaking new ground in food regime theory: Corporate environmentalism, ecological feedbacks and the 'food from somewhere' regime? Agric. Hum. Values 2009, 26, 309-319. [CrossRef] 
8. Milcu, A.I.; Sherren, K.; Hanspach, J.; Abson, D.J.; Fischer, J. Navigating conflicting landscape aspirations: Application of a photo-based Q-method in Transylvania (Central Romania). Land Use Policy 2014, 41, 408-422. [CrossRef]

9. Ignacio Gasparri, N.; Ricardo Grau, H. Deforestation and fragmentation of Chaco dry forest in NW Argentina (1972-2007). For. Ecol. Manag. 2009, 258, 913-921. [CrossRef]

10. LSN Landesamt für Statistik Niedersachsen. LSN-Online-Datenbank 2016. Available online: http://www1. nls.niedersachsen.de/statistik/default.asp (accessed on 7 December 2016).

11. LSN Landesamt für Statistik Niedersachsen. Katasterfläche nach Nutzungsarten (17) der tatsächlichen Nutzung (Gemeinde; Zeitreihe). Gebietsstand: 1.1.2015. Landwirtschaftliche Fläche (ohne Moor \& Heide) von 1997, 2015, 2018. Available online: https://www1.nls.niedersachsen.de/statistik/html/default.asp (accessed on 3 May 2018).

12. Horcea-Milcu, A.I.; Abson, D.J.; Dorresteijn, I.; Loos, J.; Hanspach, J.; Fischer, J. The role of co-evolutionary development and value change debt in navigating transitioning cultural landscapes: The case of Southern Transylvania. J. Environ. Plann. Manag. 2017, 1-18, 800-817. [CrossRef]

13. Klain, S.C.; Satterfield, T.; MacDonald, S.; Battista, N.; Chan, K.M.A. Will communities "open-up" to offshore wind? Lessons learned from New England islands in the United States. Energy Res. Soc. Sci. 2017, 34, 13-26. [CrossRef]

14. Egli, L.; Meyer, C.; Scherber, C.; Kreft, H.; Tscharntke, T. Winners and losers of national and global efforts to reconcile agricultural intensification and biodiversity conservation. Glob. Chang. Biol. 2018, 24, 1-17. [CrossRef]

15. Hargreaves, A. Inclusive and exclusive educational change: Emotional responses of teachers and implications for leadership. Sch. Leaders. Manag. 2004, 24, 287-309. [CrossRef]

16. Folke, C. Resilience: The emergence of a perspective for social-ecological systems analyses. Glob. Environ. Chang. 2006, 16, 253-267. [CrossRef]

17. Fischer, J.; Manning, A.D.; Steffen, W.; Rose, D.B.; Daniell, K.; Felton, A.; Garnett, S.; Gilna, B.; Heinsohn, R.; Lindenmayer, D.B.; et al. Mind the sustainability gap. Trends Ecol. Evol. 2007, 22, 621-624. [CrossRef] [PubMed]

18. Abson, D.J.; Fischer, J.; Leventon, J.; Newig, J.; Schomerus, T.; Vilsmaier, U.; von Wehrden, H.; Abernethy, P.; Ives, C.D.; Jager, N.W.; et al. Leverage points for sustainability transformation. Ambio 2017, 46, 30-39. [CrossRef]

19. Fazey, I.; Schäpke, N.; Caniglia, G.; Patterson, J.; Hultman, J.; van Mierlo, B.; Säwe, F.; Wiek, A.; Wittmayer, J.; Aldunce, P.; et al. Ten essentials for action-oriented and second order energy transitions, transformations and climate change research. Energy Res. Soc. Sci. 2018, 40, 54-70. [CrossRef]

20. Krohn, W. Learning from case studies. In Handbook of Transdisciplinary Research; Hirsch-Hadorn, G.H., Hoffmann-Riem, S., Biber-Klemm, W., Grossenbacher-Mansuy, D., Joye, C., Pohl, U., Wiesmann, E.Z., Eds.; Springer: Dordrecht, Germany, 2008; pp. 369-383.

21. Vilsmaier, U.; Brander, V.; Engbers, M. Research in-between: The constitutive role of cultural differences in transdisciplinarity. Transdiscip. J. Eng. Sci. 2017, 8, 169-179. [CrossRef]

22. Winkler, I. Social Landart. Ein Generator Nachhaltiger Praxis. Ph.D. Thesis, Leuphana Universität. Lueneburg, Lüneburg, Germany, July 2018.

23. Engbers, M.; Winkler, I. (Bio)Diversitätskorridor. In Vielfalt als Ausgangspunkt für Mensch E Natur im Landkreis Oldenburg. Herausgeber: Artecology_network e.V. und Leverage Points for Sustainability Transformation; Leuphana University of Lüneburg: Lüneburg, Germany, 2019; ISBN 978-3-935786-73-7.

24. Booth Sweeny, L.; Meadows, D. The System Thinking Playbook; Green Publishing: Chelsea, UK, 2010.

25. Senge, P.M. The Fifth Discipline: The Art E Practice of the Learning Organization; Crown Publishing Group: Danvers, MA, USA, 2010.

26. Flick, U. Qualitative Sozialforschung, 4th ed.; Rowohlt Taschenbuch Verlag GmbH, Reinbek bei: Hamburg, Germany, 2006.

27. Braun, V.; Clarke, V. Using thematic analysis in psychology. Qual. Res. Psychol. 2008, 3, 77-101. [CrossRef]

28. Mayring, P. Qualitative Inhaltsanalyse. In Grundlagen und Techniken, 10th ed.; Beltz Verlag: Weinheim/Basel, Switzerland, 2008.

29. Xenakis, I.; Arnellos, A.; Darzentas, J. The functional role of emotions in esthetic judgment. New Ideas Psychol. 2012, 30, 212-226. [CrossRef] 
30. Pile, S. Emotions and affect in recent human geography. Trans. Inst. Br. Geogr. 2009, 35, 5-20. [CrossRef]

31. Brehm, J.W.; Miron, A.M.; Miller, K. Affect as a motivational state. Cognit. Emotion 2009, 23, $1069-1089$. [CrossRef]

32. Mayer, S.F.; Frantz, C.M. The connectedness to nature scale: A measure of individuals' feeling in community with nature. J. Environ. Psychol. 2004, 24, 503-515. [CrossRef]

33. Perrin, J.L.; Benassi, V.A. The connectedness to nature scale: A measure of emotional connection to nature? J. Environ. Psychol. 2009, 29, 434-440. [CrossRef]

34. Boiger, M.; Mesquita, B. The construction of emotion in interactions, relationships, and cultures. Emot. Rev. 2012, 4, 221-229. [CrossRef]

35. Bodorkós, B.; Pataki, G. Linking academic and local knowledge: Community-based research and service learning for sustainable rural development in Hungary. J. Clean Prod. 2009, 17, 1123-1131. [CrossRef]

36. Mace, G.M. Whose conservation? Science 2014, 345, 1558-1560. [CrossRef] [PubMed]

37. Raymond, C.M.; Singh, G.G.; Benessaiah, K.; Bernhardt, J.R.; Levine, J.; Nelson, H.; Turner, N.J.; Norton, B.; Tam, J.; Chan, K.M.A. Ecosystem Services and Beyond: Using multiple metaphors to understand human-environment relationships. BioScience 2013, 63, 536-546. [CrossRef]

38. Bondi, L.; Davidson, J.; Smith, M. Introduction: Geography's “emotional turn”. In Emotional Geographies; Davidson, J., Bondi, L., Smith, M., Eds.; Ashgate Publishing: Farnham, UK, 2005; pp. 1-16.

39. Evely, A.C.; Pinard, M.; Reed, M.S.; Fazey, I. High levels of participation in conservation projects enhance learning. Conserv. Lett. 2011, 4, 116-126. [CrossRef]

40. Rode, J.; Gómez-Baggethun, E.; Krause, T. Motivation crowding by economic incentives in conservation policy: A review of the empirical evidence. Ecol. Econ. 2015, 117, 270-282. [CrossRef]

(C) 2019 by the authors. Licensee MDPI, Basel, Switzerland. This article is an open access article distributed under the terms and conditions of the Creative Commons Attribution (CC BY) license (http://creativecommons.org/licenses/by/4.0/). 